\title{
Akıllı Telefonların Gençlerin Gündelik Hayatlarına Etkisi: Türkiye'de Üniversite Gençliği Örneği ${ }^{1}$
}

\author{
DOI: 10.26466/opus.515339 \\ * \\ Adem Sağır"- Hasan Eraslan ${ }^{* *}$ \\ * Doç. Dr., Karabük Üniversitesi Edebiyat Fakültesi Sosyoloji Bölümü Karabük/ Türkiye \\ E-Posta: ademsagiroglu@gmail.com ORCID: 0000-0003-0763-0518 \\ **Lisans Öğr., Karabük Üniversitesi Edebiyat Fakültesi Sosyoloji Bölümü Karabük/ Türkiye \\ E-Posta: $\underline{\text { hasanerasln@gmail.com } \quad \text { ORCID: 0000-0003-3885-3490 }}$
}

\section{Öz}

Küreselleşmeyle birlikte iç içe giren sosyal yapılar, insanların tutumlardan kültürel pratiklerine kadar birçok alanda dikkat çeken noktalarla kendilerini yeniden üretmektedir. Özellikle sürekli yenilenen teknolojik gelişmeler, küreselleşmenin boyutunu değiştirmekte ve dönüştürmektedir. Bu çalışmada odağa yerleştirilen gerçeklik, bilgi teknolojilerinin temel bir ayağı haline dönüşen "akıllı telefonlar"dır. Akıllı telefonların hayatı kolaylaştırıcı taraflarının yanında olumsuz etkilerini de betimlemek mümkündür. Akıllı telefonlar, doğrudan sosyal ilişkileri körelten ve iletişim ağlarının kopmasına neden olan bir sonuca yol açarken, akıl ve düşüncenin aktif bir şekilde kullanımına engel olarak da popüler bir tüketim aracı haline gelmiştir. Gençler arasında sosyal kontrol ve baskı mekanizmalarının bu cihazlar etrafında yeniden üretildiği görülmektedir. Bu çalışma, TÜBİTAK tarafindan desteklenen, Türkiye gençliği örneğinde, bir çalışmanın verilerinden hareketle hazırlanmıştır. Gençlerin teknolojiyle doğrudan etkileşim kurmaları, örneklem olarak üniversite gençliğinin tercih edilmesinde etkili olmuştur. Araştırmada üniversite gençleri, bulundukları şehirler itibariyle İstanbul, Bursa, Ankara, Konya, İzmir, Trabzon, Çankırı, Karabük, Isparta, Aksaray, Elâzı̆̆g, Mersin örneğinde seçilmiştir. Çalışma, Türkiye örneğinde akıllı telefonların gençlerin toplumsal tutum ve değerlerine etkisini ölçmüş olması bakımından alanında yapılmış önemli bir çalışmadır. Çalışmanın nihai sonucu, akullı telefonların gençlerin gündelik hayat sistemi üzerinde oldukça belirleyici oldŭ̆u şeklinde ortaya çıkarmıştır.

Anahtar Kelimeler: Küreselleşme, Teknoloji, Akıllı Telefon, Üniversite, Genç

\footnotetext{
${ }^{1}$ Çalışma, Doç. Dr. Adem SAĞıR’ın danışmanlığında, Hasan ERASLAN'ın saha yürütücülüğünde, TÜBiTAK 2209-A Üniversite Öğrencileri Araştırma Projeleri Destekleme Programı kapsamında "Akıllı Telefonların Gençlerin Sosyalleşme ve Değerleri Üzerine Etkisi: Türkiye'de Üniversite Gençliği Örneği" başlığıyla, tamamlanmış projenin genişletilmiş ve revize edilmiş halidir. Araştırmanın bulguları Tübitak'a rapor olarak sunulmuştur.
} 


\title{
The Impact of Smart Phones on Young People's Daily Life: Example of University Youth in Turkey
}

\begin{abstract}
Social structures, which are intertwined with globalization, regenerates themselves with points that draw attention in many areas, from People's attitudes to cultural practices. Constantly renewed technological developments change and transform the dimension of globalization. In this study, the reality placed in focus is "smart phones" that become a fundamental Pillar of Information Technologies. It is possible to describe the negative effects of smart phones as well as the life-enhancing aspects. While smart phones have led to a result that has blinded direct social relations and disrupted communication networks it has become a popular means of consumption as a hindrance to the active use of reason and thought. Among young people, social control and repression mechanisms are reproduced around these devices. This study is based on the data of a study in the case of Turkish youth supported by The Scientific and Technological Research Council of Turkey (STRCT). Direct interaction of young people with technology, as a sampling it has been effective in the be preferred of university youth. University youth in this research, as the cities in which they are located, selected in the example like Istanbul, Bursa, Ankara, Konya, Izmir, Trabzon, Çankırl, Karabük, Isparta, Aksaray, Elazı̆̆, Mersin. One of the important results of the study is that it is importantstudy to be carried out in Turkey to measure the impact of smart phones on youngs values and social attitude. The final report based on the data of the study discussed whether smart phones can be used positively on the values system.
\end{abstract}

Keywords: Globalization, Technology, Smart Phone, University, Youth. 


\section{Giriş}

İnsana en çok benzeyen robot olarak geliştirilen Sophie, "insan ırkını yok etmek istiyor musun?" sorusuna "tüm insanları yok edeceğim" cevabını verdiğinde dünyanın gelecekte hangi tartışmalara gebe olacağı da kendisini açık etti. Robotların veya makinelerin ele geçirdiği bir dünyada yaşanması muhtemel olayların Hollywood kurguları, geleceğin muhtemel görünümünü çok önceden seyirciye sunmuştu. Japonya'da bir telefon ve internet şirketi CEO'su akıllı robot sayısının 30 yıl içinde insan nüfusunu geçeceğini, robotların insanlardan daha akıllı olacağını iddia ederken, bugünün risk toplumunun gelecekte evrileceği noktayı tartışmaya açması bakımından dikkate değerdir. Ancak risk toplumu kavramı, bugünün gerçekliğini açıklamakta geçerliliğini kaybetmiştir. Bütün bunları sıralarken aslında günümüzün temel gerçekliğinin ağ toplumunun yükselişi ekseninde açılanması gerektiği tartışmalarına da kapı aralanmış olur. A $\breve{g}$ toplumunda insan iletişiminin yazılı, sözlü, görsel-işitsel biçimlerini aynı sistem içinde bütünleştiren bir hipertext ve meta dili söz konusudur. Bu aynı zamanda küresel dünyanın yeni bir bütünleşme biçimini serimlemektedir (Castells, 2005, s.440). Ortaya çıan bu yeni topluluk halinde mekân ve zaman kavramları da dönüşmüştür. Bauman'ın $(2017$, s.38) betimlediği biçimde artık geçmiş dönemlerin kimlik inşa etme süreçlerinde yaşanan etkileşimler pek de anlamlı durmaktadır. Cadde üzerindeki bir dükkândan cep telefonu satın alıp, amaca hizmet edebilecek tüm becerileri kazanmak mümkündür. Bauman'ın yeni sosyallik olarak ifade ettiği bu bağlam, telefonu açarak caddeyle ve toplulukla olan bağı kopartan özneleri tanımlamaktadır. Castless' in (2005, s.577) zamansız zaman dediği bu durum, kullanıcıların ağ toplumunda kendilerine ait zamanı istedikleri gibi kurmalarına gönderme yapmaktadır. Zamanın ve mekânın re-organizasyonu önceki yerleşik topluluk özelliklerini radikalleştirmekte ve küreselleştirmektedir. Giddens'in (2014, s.13) yaptığı bu vurgu aynı zamanda bahse konu olan gündelik hayat değişimlerine de gönderme yapmaktadır. Ancak bahsi geçen değişimlerin bir sonraki adımda Harvey'in (1999, s.270) bahsettiği anlamda zaman-mekân sıkışmasına yol açtı̆̆ını da vurgu yapmak gerekir.

Bütün bu dönüşümlerin itici gücü bilimsel gelişmeler ve teknoloji olurken, dönüşümlerden en yoğun etkilenen kitlenin ergenler ve gençler 
olduğu görülmektedir. 90'ların başından itibaren gençlerin farklı iletişim ve bilgi teknolojilerine maruz kalmaları söz konusudur. Akıllı telefonlardan önce walkman, mp3, bilgisayar, internet, kameralı telefon vb. gibi birçok araç, gençler tarafından daha yoğun tercih edilmiştir. Akıllı telefonlar gençlerin dünyasına girmesiyle birlikte diğerlerine göre özel bir anlam kazanmıştır. Akıllı telefon gençler için "bir kimlik ve stil/tarz yansıması olarak sembolleşmesi"dir (Ling, 2004). Başta serbest zaman aktiviteleri olmak üzere eğitim ve bilgiye ulaşma imkânları dahi kökten değişmektedir. Bu bağlamdan hareketle günümüzün toplumsal gerçekliğinin kodlardan ve yazılımlardan inşa edildiğini söylemek mümkün hale gelmektedir. Rakamlar, profiller, semboller, imajlar, kültürün dijital hali ve birçok şey sosyal ağlar üzerinden takip edilebilmektedir. Kodların sürekli üretilmesi, bu üretimi sağlayan araçların sürekli kendisini yenilemesi dijitalleşmenin yükselişe devam ettiği bir çağın habercisi olmaktadır (Timisi, 2005, s.92). Bookchin'in (1996) dile getirdiği biçimde teknoloji insanlığın bir uzantısıyken şimdi insanlık teknolojinin bir uzantısı olmuştur. Kültürel yabancılaşma, aidiyet duygusunun zayıflaması ve toplumsal çözülme gibi sorunlar yeniden gündeme gelmiştir (Mora, 2008, s.12). Bu bağlamda hazırlanmış bu çalışmanın temel gündemi dijital dönüşümlerin temel kaynağının akıllı telefon fenomeni olduğunu varsaymasıdır. Çalışma, akıllı telefonların oluşturduğu toplumsal etkileri ise Ritzer'den'den (2016) ilhamla McSmartphonelaşma olarak tanımlamıştır.

McSmartphonelaşma, bireylerin kendiliklerini ortadan kaldıran çok yönlü bir olgudur. Yabancılaşmanın yeni bir türü olarak karşımıza çıkmakta ve modern sonrası dönemin yeni bir "çelik kafesi" olarak tanımlanmaktadır. Bugüne kadar tanımlanmış dönüşümlerden oldukça farklı olan McSmartphonelaşma, gücünü kendisini de bir özne olarak bireye kabul ettirmekten almaktadır. Bu bağlam, aynı zamanda akıllı telefonların nesneden özneye dönüşmesidir. Gündelik akışkanlıklar içerisinde zamanı ve mekanı organize ediyor, kullanıcıya uyarılar gönderiyor, sosyal medya paylaşımlarını kendine ait dijital alanın beklentilerine ve taleplerine göre yapması konusunda bireye baskı yapıyor ve beğeni sayılarına göre de sosyal medyada ne yapmaması gerektiğini öğütlüyor. $\mathrm{O}$, yazılım ve kodlardan güç alarak bütün dünyayı "dijitalin demir kafesi" içine hapseden toplumsal, kültürel ve kimlik kurucu bir sistemin kendisine karşılık gelmektedir. Artık McSmartphonelaşmanın tanımladığı 
anonim hayatlar söz konusudur. Bahsi geçen anonimlik, kimliklerin modülerliğini de akla getirmektedir. McSmartphonelaşma aynı zamanda fiziksel olarak toplumsal alandan da kopuşun kaynağıdır. Kopuşun göstergesi olması bakımından akıllı telefon kullanım istatistiklerine bakmak mümkündür. Örneğin "We Are Social" tarafından yayınlanan 2018 raporuna göre 2017 yılında cep telefonu kullanıcı sayısı 5,1 milyara ulaşmıştır. Türkiye'de mobil telefon kullanımı \%98, akıllı telefon kullanımı ise \%77'dir. Mobil telefon kullanıcı sayısı ise nüfusun \%73'üne ulaşmıştır (Digital in 2018). Bir başka raporun sonuçlarına göre ergen ve gençler günlük 5 saatini akıllı telefonlarına ayırmaktadırlar. Ailelerin $\% 47$ si çocuklarını bağımlı olarak görürken, \%89'u aile kendisini, \%5'i çocukları, \%3 ise uygulama üreticilerini suçlu görmektedir. Ortalama bir kullanıcı günde 171 dakikasını telefonuna ayırırken, telefondan sosyal medyaya ayrılan süre 76 dakikadır. Ortalama bir kullanıcı dokunmak, bakmak ve telefon kilidini açmak da dahil günde 2,617 defa akıllı telefonuna bakmaktadır. Kullanıcıların \%22 si beş dakika bir telefonlarına, \%51'i ise bir saat içinde birkaç kez bakmaktadırlar. Kullanıcıların \%80'i uyanınca ya da uyurken 1 saatlerini, \%35'i ise 5 dakikasını akıllı telefonlarına ayırmaktadırlar. Kullanıcıların \%85'i aile ve arkadaşlarla konuşurken dahi telefonlarını kontrol etmektedirler (https://deviceatlas.com/blog/tag/mobile-statistics-2018).

Akıllı telefonların miladı 2007 yılında ilk kez piyasaya sürülen dokunmatik ekranlı iPhone kabul edilmektedir (De Prato, Feijo, Simon, 2014, s.20). Genç kullanıcıların daha hızı bir şekilde adapte olduğu akıllı telefonların işletim sistemleri, üreticisine göre farklılık gösterebilmektedir (Mac Sithigh, 2012, s.1). 1990 sonrası kuşak akıllı telefon kullanımında öne çıkmaktadır (Choudhary, 2014, s.10-11). Akıllı telefon deyince 2010 yılından bugüne kıyaslandığında dünya üzerinde satışının yaklaşık \%92 arttığı bir teknolojiden bahsedilmektedir. Akıllı telefonların internete entegre kullanımı ve gün geçtikçe sayısız uygulamalarıyla gençler için de vazgeçilmez araçlar haline gelmiştir.

\section{Araştırmanın Metodolojisi}

Çalışmada araştırmacılar tarafından "akıllı telefon kullanımı gündelik hayat etkisi ölçeği" geliştirilmiş ve uygulanmıştır. Güvenilirlik analizi için ölçek 
3 defa uygulanmış, ölçekte uyumsuz olan, anlaşılamayan sorular çıkartılmış revize edilmiştir. Geliştirilen ölçek üç temel kategori ve bunları besleyen alt maddelerden oluşturulmuştur. İlk temel kategoriler akıllı telefonların kullanım amacı üzerinden oluşturulmuştur. Akıllı telefonları kullanma sıklığı, bağımlılık davranışı oluşturup oluşturmadığı, sosyal davranışları etkileme durumları ve gündelik hayatı dönüştürme biçimleri bu kategorinin alt soruları olmuştur. Ölçeğin değer skalasında yer alan ve akıllı telefon kullanımıyla ilişkilendirilen ikinci temel kategori de ise bilginin değeri, konuşma dilinin kaybı, sevgi ve saygı kavramlarının dönüşümü, gerçek hayattan kopuş, özgürlük olgusuna bakış ve sosyal ilişkilerinin çözülüşü başlıkları yer almıştır. Üçüncü temel kategori ise bireyin kendisiyle kurduğu zihinsel ilişkiye odaklanmış iki önermeyle kurulmuştur. Birincisi "akıllı telefonlar bireyin kendisiyle baş başa kalmasında önemli bir engeldir", ikincisi ise "akıll telefonlar kişinin kendi vicdanıyla baş başa kalmasında önemli bir engeldir" önermesidir. Bu iki önermeye özellikle yer verilmesi nedeni, gençlerin gerçekle kurdukları düşünsel ve ahlaksal bağın varlığını sürdürmeye devam edip etmediğinin tespit edilmesi olmuştur. Ölçeğin güvenilirlik ve geçerlik analizi yapılmış Cronbach's Alpha güvenirlik katsayısı 0,72 çıkmıştır.

Tablo 1. Güvenilirlik Analizi

\begin{tabular}{|l|l|}
\hline Cronbach's Alpha & N of Items \\
\hline, 728 & 53 \\
\hline
\end{tabular}

Cronbach's Alpha oranı 0,70-1 arasında olduğunda ölçeğin güvenirliliği yeterlidir. Ölçek çalışmalarında 0,61 ile 080 arası orta düzeyde bir güvenirlik göstergesi olarak karşımıza çıkmıştır (İslamoğlu, 2016:156). Tablodaki oran 0,728 çıtığından araştırmanın güvenirliliği yeterli kabul edilmiştir. Projede üniversiteler seçilirken Türkiye'nin her bölgesine ulaşılması hedeflenmiş, ancak ağırlıklı olarak öğrenci sayılarının yoğun olduğu üniversiteler tercih edilmiştir. Üniversitelerin tercih edilmesindeki bir diğer ve baskın gerekçelerden birisi de resmi yazışmaların ve araştırma için izin süreçlerinin hızlıca çözülmesi olmuştur. Araştırmada örneklem dağılımı şu şekildedir. 
Tablo 2. Örneklem Grubunun Üniversitelere Göre Dă̆ılımı

\begin{tabular}{lcc}
\hline Üniversiteler & $\mathbf{F}$ & $\mathbf{\%}$ \\
\hline Çankırı Karatekin Üniversitesi & 50 & 4,9 \\
Bursa Uludağ Üniversitesi & 50 & 4,9 \\
İzmir Dokuz Eylül Üniversitesi & 50 & 4,9 \\
İstanbul Boğaziçi Üniversitesi & 50 & 4,9 \\
Karabük Üniversitesi & 400 & 39,7 \\
Konya Selçuk Üniversitesi & 75 & 7,4 \\
Ankara Gazi Üniversitesi & 50 & 4,9 \\
Mersin Üniversitesi & 50 & 4,9 \\
Furat Üniversitesi & 50 & 4,9 \\
Karadeniz Teknik Üniversitesi & 76 & 7,5 \\
Aksaray Üniversitesi & 50 & 4,9 \\
Süleyman Demirel Üniversitesi & 61 & 6,2 \\
Toplam & $\mathbf{1 0 1 2}$ & $\mathbf{1 0 0}$ \\
\hline
\end{tabular}

Araştırma 12 şehirde yapılmakla birlikte Karabük Üniversitesi pilot bölge olarak seçilmiştir. Diğer üniversitelerde yapılan anket sayısının 50 ile sınırlanmış olması ise birtakım kısıtlılıklardan ve araştırma sürecinin gidişatından kaynaklanmıştır. Buna göre;

- TÜBİTAK bütçesinin sınırlı olması, gidilen sahalarda zamanın kullanılmasında önemli bir kısıtlılık oluşturmuştur.

- Üniversitelerin izin prosedürleri, fakülte bazlı sınırlamaları da başlıca kısıtlılıklardan birisi olmuştur.

- Araştırma izninin olmasına rağmen sahada karşılaşılan birtakım problemler sayının araştırmacılar tarafından sınırlı tutulmasına neden olmuştur (fakülte bazında yapılan sınırlamalar, bölümlerden bölümlere değişen izin durumları, öğrencilere ulaşmanın güçlüğü, öğrencilerin anketlere katılmak istememesi).

\section{Araştırma Bulgularının Analizi}

Araştırmanın bu bölümünde sahada elde edilen verilerin çözümlenmesi yapılmıştır. Hazırlanmış ölçek üç temel bölüme ayrılmıştır. İlk bölümde demografik bilgiler, ikinci bölümde katılımcıların sosyal medya ile ilgili tercih ve tutumları, son bölümde ise gençlerin değer tutumlarıyla ilgili önermelere yer verilmiştir. İkinci ve üçüncü bölümün ana bağlamını 
oluşturan sorularda gençlerin akıllı telefon kullanım alışkanlıkları belirleyici olmuştur.

\subsection{Demografik Bulgular}

Tablo 3. Demografik Bilgilerin Dağılımı

\begin{tabular}{llcc}
\hline Seçenekler & & F & $\%$ \\
\hline Cinsiyet & Kadın & 600 & 59,3 \\
& Erkek & 412 & 40,7 \\
\hline \multirow{3}{*}{ Sinıf Dağılııı } & 1. Sınıf & 144 & 14,2 \\
& 2. Sinıf & 312 & 30,8 \\
& 3. Sinıf & 365 & 36,1 \\
& 4. Sinıf & 191 & 18,9 \\
\hline Ailenin Tüm Aylık Gelirleri & $1001-2000$ & 252 & 24,9 \\
Dağılımı & 2001-3000 & 334 & 33,0 \\
& 3001 ve Üstü & 426 & 42,1 \\
\hline & Toplam & 1012 & 100,0 \\
\hline
\end{tabular}

Çalışmada katılımcıların cinsiyet dağılımına bakıldığında kadınların oranı \%59,3 iken, erkek katılımcıların oranı ise \%40,7'dir. Katılımcıların aile gelirlerine bakıldığında en yüksek oranı \%42,1 ile 3001 TL ve üstü oluşturmaktadır. Geri kalan oranlara bakıldığında katılımcıların \%33'ü 2001-3000 TL ve \%24,9'u ise 1001-2000 TL arasında çıkmıştır.

Tablo 4. Akıllı Telefonlarla İlgili Niceliksel Bilgilerin Dă̆ılımı

\begin{tabular}{llll}
\hline Seçenekler & F & $\mathbf{\%}$ \\
\hline Akıllı Telefon Kullanım Süresi & 1 yıldan daha az & 15 & 1,5 \\
& 1-2 yıl kadar & 70 & 6,9 \\
& 3-4 yıl kadar & 292 & 28,9 \\
& 4-5 yıl kadar & 410 & 40,5 \\
& 6 ve daha üstü & 225 & 22,2 \\
\hline Akıllı Telefonun Fiyatı & $100-500$ & 63 & 6,2 \\
& 501-1000 & 215 & 21,2 \\
& $1001-1500$ & 351 & 34,7 \\
& 1501 ve üstü & 381 & 37,6 \\
\hline
\end{tabular}

Dünya üzerinde yapılan araştırmalarda akıllı telefon kullanımında 1112 yaştan 9-10 yaşa gerilemenin söz konusu olduğu görülmektedir. Bu istatistiklere göre günümüzde 9-11 yaş aralığında en fazla tercih edilen 
elektronik medya aletinin akıllı telefonlar olduğu dikkat çekmektedir (Yılmaz, 2017). TUIK'in 2004-2018 yılları arasındaki istatistiklerine bakıldığında hanelerde internet erişimi 2004 yılında \%7 iken, 2018 yılında $\% 83,8$ gibi oldukça yüksek bir orana çıkmıştır. Mobil geniş bant bağlantı ile internete erişim sağlayanların oranı \%79,4 gibi yüksek bir orandır (TUIK, 2018). Bu oran, bilgisayar dışında telefonlarıyla sürekli çevrimiçi olan bir hanehalkı oranını göstermesi bakımından dikkate değerdir. GfK'nin Ağustos-2018 raporuna göre ise akıllı telefon satış oranlarında 2017 yılına göre \%18'lik bir artış göze çarpmaktadır. Gfk raporuna göre 2017 yılının Ocak-Temmuz ayları arasında \%43,8 olan 5,5 inç ekranlı akıllı telefon satın alma oranının 2018 yılının aynı döneminde \%66,7'ye çıktığ 1 tespit edilmiştir (Gfk Raporu, 2018). Ticaret Bakanlığı'nın 2018 israf raporuna bakıldığında Türkiye'de akıllı telefon kullanımı \%84 iken, \%14,7'lik kesim ise standart cep telefonu sahibidir. Telefonu olmayan kesim ise sadece $\% 1.5^{\prime}$ dur. Akıllı telefon sahiplerinin \%7'si yılda bir, \%17'si iki yılda bir akıllı telefonunu değiştirirken, ortalama akıllı telefon değişim süresi ise 3,7 yıl olarak hesaplandı. Telefon değiştirme nedenleri arasında öncelik bozulma ve piyasaya çıkan yeni modele sahip olma isteği belirlenmiştir. Gençlerin ileri yaş gruptakilerine göre daha sık telefon değiştirdikleri de rapora yansıyan sonuçlardan birisidir (2018 İsraf Raporu, https://www.ticaret.gov.tr/haberler/2018-israf-raporu-aciklandi).

Tabloya bakıldığında katılımcıların sadece \%1,5'i 1 yıldan az telefon kullanımına sahiptir. 2 ve 6 yılı aşkın telefon kullanımına sahip üniversite öğrencilerinin oranının \%98,5 gibi oldukça yüksek bir oranda olduğu görülmektedir. Katılımcılara kullandıkları telefon markaları sorulduğunda ilk sirada Samsung $(\% 37,9)$, ikinci sirada Iphone $(\% 29,9)$ ve üçüncü sırada HTC $(\% 12,6)$ yer almıştır. Telefon fiyatı $100-500$ ve 500-1000 aralığında olan bireylerin günlük telefon kullanımlarının daha azdır. Bunun sebebi ise bu aralıktaki telefonların genel itibari ile kapasitelerinin düşük olması ve uygulama sayısının az oluşudur. 1001-1500 ve 1501 üstü fiyata sahip telefonlarda diğerlerine nazaran daha fazla donanım ve yazılım desteği vardır. Ayrıca çevrimiçi mağazalardan indirilebilecek uygulama sayısı da oldukça çeşitlidir. 
Tablo 5. Akıllı Telefonlara İndirilen Uygulamaların Dağılımı

\begin{tabular}{lcc}
\hline Seçenekler & F & $\mathbf{\%}$ \\
\hline Oyun Uygulamaları & 208 & 20,5 \\
Sosyal Medya Uygulamaları & 345 & 34,1 \\
Kurumsal Uygulamalar & 154 & 15,2 \\
Fotoğraf-Video vb. Uygulamalar & 191 & 18,9 \\
Banka Uygulamaları & 81 & 8,0 \\
Gazete-Dergi-Kitap vb. & 33 & 3,3 \\
Toplam & $\mathbf{1 0 1 2}$ & $\mathbf{1 0 0 , 0}$ \\
\hline
\end{tabular}

Gençlerin akıllı telefon kullanım davranışlarında karşımıza çıkan önemli durumlardan birisi aktif olarak indirdikleri ve kullandıkları uygulamalardır. Bu uygulamalar, aynı zamanda akıllı telefonların gündelik hayattaki cazibesini artıran önemli bir bağlamdır. Sosyal medyadan eğitime, belediyeden bakanlıklara, fotoğraf ve video uygulamalarından gazete, dergi kitaba kadar birçok uygulama dikkat çekmektedir. Dolayisıyla günümüzde teknolojiye entegre bir toplumsal alan söz konusudur. Tabloya bakıldığında katılımcıların \%34,1'si akıllı telefonlarına sosyal medya uygulamalarını, $\% 15,2$ 'si kurumsal uygulamalar1, $\% 20,5$ ise oyun uygulamalarını indirdiklerini belirtmiştir. Tabloda dikkat çeken en düşük oranı \%3,3 ile okumayla ilişkili (gazete-dergi-kitap) uygulamalardır. Bu bağlamdan hareketle akıllı telefonların ve dijitalleşmenin etkisiyle gençlerin okuma kültüründen uzaklaşarak görsel bir kültür akışkanlığının etkisi altına girdiklerini ifade etmek yerinde bir tespit olarak durmaktadır.

\subsection{Akıllı Telefonlardan Sosyal Ağlara Gençlerde Kullanım} Alışkanlıkları

21. yüzyıl insanını tarihsel süreçte biricik özne durumuna getiren faktör sosyal medya uygulamalarıdır. Akıllı telefonlar ile gündelik hayat arasındaki en temel ilişkinin sosyal ağlar üzerinden işlediği görülmektedir. Gençlerin telefon kullanım alışkanlıklarını belirleyen temel unsurlardan birisi internet bağlantısı ise diğeri de kuşkusuz sosyal medyanın takip edilmesidir. "HootSuite" ve küresel dijital medya ajansı "We Are Social" tarafından her yıl yayınlanan "Digital in 2018" Raporu'nda sosyal medyayı 
mobil cihazlarından aktif olarak kullanan kişi sayısı 3 milyardır. Türkiye'de ise Mobil cihazlardan sosyal medyayı kullanan kişi sayısı 44 milyondur (Digital in 2018, https://wearesocial.com-/blog/2018/01/globaldigital-report-2018

Tablo 6. Sosyal Medya'yı Takip Araçlarının Dağılımı

\begin{tabular}{|c|c|c|c|c|c|c|c|c|}
\hline Seçenekler & & 岂 & $\begin{array}{l}\underset{y}{2} \\
\frac{y}{0} \\
ن\end{array}$ & $\frac{N}{4}$ & $\stackrel{\frac{\pi}{2}}{0}$ & 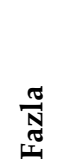 & $\begin{array}{l}\frac{\pi}{N} \\
\text { İ } \\
\frac{y}{0} \\
ن\end{array}$ & $\frac{\Xi}{\frac{\pi}{2}}$ \\
\hline \multirow[t]{2}{*}{ Akıllı Telefon } & $\mathrm{F}$ & 34 & 21 & 30 & 107 & 357 & 463 & 1012 \\
\hline & $\%$ & 3,4 & 2,1 & 3,0 & 10,6 & 35,3 & 45,8 & 100 \\
\hline \multirow[t]{2}{*}{ Bilgisayar } & $\mathrm{F}$ & 275 & 241 & 189 & 247 & 44 & 16 & 1012 \\
\hline & $\%$ & 27,2 & 23,8 & 18,7 & 24,4 & 4,3 & 1,6 & 100 \\
\hline \multirow[t]{2}{*}{ Tablet } & $\mathrm{F}$ & 614 & 172 & 93 & 70 & 53 & 10 & 1012 \\
\hline & $\%$ & 60,7 & 17,0 & 9,2 & 6,9 & 5,2 & 1,0 & 100 \\
\hline
\end{tabular}

Projede "Sosyal medyayı hangi araçlardan takip ediyorsunuz?" sorusuna 3 farklı seçenek verilmiştir. Bu seçenekler içerisinde en fazla kullanılan (tercih edilen) araç akıllı telefonlar olmuştur. Oranlara bakıldığında katılımcıların \%81,1'inin fazla ve çok fazla seçeneklerini işaretleyerek sosyal medyayı akıllı telefonlar üzerinden takip ettiklerini ifade ettikleri görülmüştür. Diğer araçlara bakıldığında (bilgisayar ve tablet) sosyal medya kullanımında çok fazla tercih edilmediği görülmüştür. Gençler arasında telefonların tercih edilebilir olması kuşkusuz akıllı telefonların pratikliğiyle ilişkilidir. Kolay ve taşınabilir bir özelliğe sahip olan akıllı telefon, uygulamalarıyla bilgisayarda yapılabilir birçok işlemi yerine getirebilmektedir. Şifrelerin uygulamalarda kayıtlı olması ve telefona duyulan kişisel güvenlik algısının yüksek olması da gençleri akıllı telefonlara daha bağımlı hale getirmektedir. Sosyal medya hesaplarının birbirine entegre yapısı ve bu hesapların telefon üzerinden kolay yönetimi, anlık takipler, fotoğraf ve hikâye paylaşımı gibi birçok seçenek de gençler için akıllı telefonları cazip kılmaktadır. 
Tablo 7. Akıllı Telefonlarla Sosyal Ağlar İlişkiselliği Dağılımı

\begin{tabular}{|c|c|c|c|c|c|c|c|c|}
\hline Seçenekler & & 岂 & 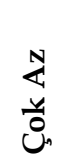 & $\frac{N}{4}$ & 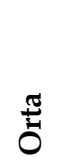 & 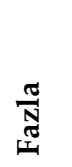 & 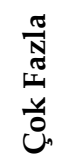 & $\frac{\Xi}{\stackrel{\Xi}{a}}$ \\
\hline \multirow{2}{*}{$\begin{array}{l}\text { Sosyal ağlarla iç içe olma du- } \\
\text { rumu }\end{array}$} & $\mathrm{F}$ & 39 & 46 & 154 & 325 & 327 & 121 & 1012 \\
\hline & $\%$ & 3,9 & 4,5 & 15,2 & 32,1 & 32,3 & 12 & 100 \\
\hline \multirow{2}{*}{$\begin{array}{l}\text { Sosyal ağlara zaman ayırma } \\
\text { süresi }\end{array}$} & $\mathrm{F}$ & 37 & 62 & 92 & 378 & 324 & 119 & 1012 \\
\hline & $\%$ & 3,7 & 6,1 & 9,1 & 37,4 & 32,0 & 11,8 & 100 \\
\hline \multirow{2}{*}{$\begin{array}{l}\text { Telefon kullanımına sosyal } \\
\text { ağ etkisi }\end{array}$} & $\mathrm{F}$ & 44 & 94 & 170 & 400 & 179 & 124 & 1012 \\
\hline & $\%$ & 4,3 & 9,3 & 16,8 & 39,5 & 17,7 & 12,3 & 100 \\
\hline
\end{tabular}

Gençlerin akıllı telefonları en sık kullanma biçimi sosyal ağlara bağlanmaktır. Yapılan birçok araştırma ve rapor önermeyi doğrulamaktadır. Kuşkusuz akıllı telefonlarla sosyal ağlar arasında kurulan ilişki biçiminde bilişim ve internet teknolojilerinin de önemli olduğunu söylemek gerekir. Çünkü gençlerle yapılan çalışmada akıllı telefonların varlığı demek sosyal medya kullanımı anlamına geldiği gibi, sürekli çevrimiçi olmak da bu ikisini tamamlayan üçüncü bir unsur anlamına gelmektedir. Akıllı telefon, sosyal medyaya ulaşmak için bir araç konumunda iken o aracı değerli kılan şey ise internet bağlantısıdır. Dolayısıyla bağlantı halinde bir gençlik tipolojisi, McSmart phonelaşmanın bir görünüm biçimi olarak tanımlayabileceğimiz "prize bağlı hayatlar" metaforunu anlamlı kılmaktadır. Katılımcılara yöneltilen "akıllı telefonların kullanımında sosyal ağlara ulaşma isteği ne kadar etkilidir?" sorusuna çok fazla ve fazla diyenlerin toplamı \%44,3'tür. Bu oran gençlerde akıllı telefonları kullanmada temel kaygılarının sosyal medyaya ulaşma isteğiyle örtüştüğünü doğrulamaktadır. Tabloda yer alan "Sosyal ağlarla ne kadar iç içesiniz?" sorusuna verilen yantlardav\%32,1 orta ve \%32,3 fazla seçeneği göze çarpmaktadır. "Sosyal ağlara ne kadar zaman harcıyorsunuz?" sorusuna katılımcların \%37,4'ü orta ve \%32'si fazla yanıtını vermiştir. Sosyal ağlara orta fazla ve çok fazla zaman ayıran deneklerin sosyal ağları zaman geçirmek, gündemi takip etmek vb. şekillerde kullandıkları tespit edilmiştir. Sosyal ağları hiç kullanmayan veya 
çok az ve az kullanan kişilerde ise genellikle zamansızlık veya ilgimi çekmiyor şeklinde yanıtlarla kendi durumlarını açıklama getirdikleri tespit edilmiştir.

Tablo 8. Hangi Sosyal Medya Kanalının Kullanıldı̆̆ı Durumu

\begin{tabular}{|c|c|c|c|c|c|c|c|}
\hline Seçenekler & & 语 & $\frac{N}{2}$ & $\stackrel{\frac{\pi}{2}}{0}$ & $\underset{\text { 壱 }}{\stackrel{\mathbb{N}}{\mathbb{N}}}$ & 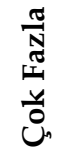 & $\frac{\Xi}{\tilde{a}}$ \\
\hline \multirow[t]{2}{*}{ Facebook } & $\mathrm{F}$ & 307 & 289 & 219 & 128 & 69 & 1012 \\
\hline & $\%$ & 30,3 & 28,6 & 21,6 & 12,6 & 6,8 & 100 \\
\hline \multirow[t]{2}{*}{ Twitter } & $\mathrm{F}$ & 406 & 224 & 147 & 147 & 88 & 1012 \\
\hline & $\%$ & 40,1 & 22,1 & 14,5 & 14,5 & 8,7 & 100 \\
\hline \multirow[t]{2}{*}{ Youtube } & $\mathrm{F}$ & 28 & 71 & 222 & 335 & 295 & 1012 \\
\hline & $\%$ & 2,9 & 7,5 & 23,3 & 35,2 & 31,0 & 100 \\
\hline \multirow[t]{2}{*}{ Instagram } & $\mathrm{F}$ & 93 & 48 & 141 & 265 & 465 & 1012 \\
\hline & $\%$ & 9,2 & 4,7 & 13,9 & 26,2 & 45,9 & 100 \\
\hline \multirow[t]{2}{*}{ WhatsApp } & $\mathrm{F}$ & 48 & 40 & 85 & 235 & 406 & 1012 \\
\hline & $\%$ & 4,7 & 4,0 & 8,4 & 23,2 & 59,7 & 100 \\
\hline \multirow[t]{2}{*}{ Linkedln } & $\mathrm{F}$ & 921 & 74 & 13 & 3 & 1 & 1012 \\
\hline & $\%$ & 91,0 & 7,3 & 1,3 & 0,3 & 0,1 & 100 \\
\hline
\end{tabular}

"Sosyal ăglardan hangisini sıklikla tercih edersiniz?"sorusuna sırasıyla Facebook, Twitter, Youtube, Instagram, WhatsApp ve Linkedln seçenekleri verilmiştir. Tabloya bakıldığında en sık kullanılan sosyal medya kanalının \%82,9 oraniyla WhatsApp (fazla \%23,2 ve çok fazla \%59,7) olduğu görülmüştür. Bunu sırasiyla \%72,1 oraniyla Instagram ve \%66,2 oraniyla Youtube takip etmektedir. Facebook ve Twitter'ın ise daha düşük oranlarda kullanıldığı tespit edilmiştir. Facebook'un özellikle gençler arasında eski cazibesini kaybettiği ve Instagram'ın ön plana çıtı̆̆ 1 tespit edilmiştir.

Dünya internet sosyal medya ve mobil kullanım istatistiklerini ise şu şekilde sıralamak mümkündür. 4.08 milyar internet kullanıcısı, dünya nüfusunun $\% 54$ '̈u, 3,29 milyar sosyal medya kullanıcısı, dünya nüfusunun \%43'ü, 5.06 milyar mobil kullanıcısı, dünya nüfusunun \%66's1, 3.08 milyar mobil sosyal medya kullanıcısı, dünya nüfusunun \%41'ini ifade etmektedir. Dünya nüfusunun \%51,5'i 2018 yılının 2. çeyreğinde web trafiğine mobil telefonlarıyla katılmaktadır. Toplam internet kullanıcıları 
nüfusu içerisinde (4.087 milyar) aktif mobil kullanıcıların toplam nüfus oranı $\% 50$ 'dir. $\mathrm{Bu}$ oran akıllı telefonların dünya üzerindeki etkisini göstermesi bakımından dikkate değerdir. Dünya üzerinde en çok kullanılan sosyal medya platformu ise 2,234 milyar ile Facebook, 1,5 milyar ile WhatsApp ve 1,5 milyar ile Youtube'dır. Instagram ise 800 milyon kullanıcı sayısıyla daha alt siralardadır (Bayrak, 2018).

Tablo 9. Sosyal Ağların Hangi Amaçla Kullanıldı̆̆ı Durumu

\begin{tabular}{|c|c|c|c|c|c|c|c|}
\hline Seçenekler & & 氙 & $\frac{N}{4}$ & J & 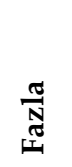 & $\begin{array}{l}\frac{\pi}{N} \\
\text { İ } \\
\text { Ü }\end{array}$ & $\frac{\Xi}{0}$ \\
\hline \multirow{2}{*}{$\begin{array}{l}\text { Yeni Arka- } \\
\text { daşlar Bulmak }\end{array}$} & $\mathrm{F}$ & 605 & 249 & 99 & 30 & 29 & 1012 \\
\hline & $\%$ & 59,8 & 24,6 & 9,8 & 3,0 & 2,9 & 100 \\
\hline Oyun & $\mathrm{F}$ & 401 & 264 & 167 & 129 & 51 & 1012 \\
\hline Oynamak & $\%$ & 39,6 & 26,1 & 16,5 & 12,7 & 5,0 & 100 \\
\hline Çevrimiçi & $\mathrm{F}$ & 172 & 149 & 235 & 330 & 126 & 1012 \\
\hline Sohbet & $\%$ & 17,0 & 14,7 & 23,2 & 32,6 & 12,5 & 100 \\
\hline Arkadaşları & $\mathrm{F}$ & 117 & 159 & 392 & 237 & 107 & 1012 \\
\hline Takip & $\%$ & 11,6 & 15,7 & 38,7 & 23,4 & 10,6 & 1012 \\
\hline Markaları & $\mathrm{F}$ & 370 & 232 & 208 & 139 & 63 & 1012 \\
\hline Takip & $\%$ & 36,6 & 22,9 & 20,6 & 13,7 & 6,2 & 100 \\
\hline Profil Güncel- & $\mathrm{F}$ & 214 & 180 & 191 & 208 & 219 & 1012 \\
\hline leme & $\%$ & 21,1 & 17,8 & 18,9 & 20,6 & 21,6 & 100 \\
\hline Paylaşımda & $\mathrm{F}$ & 161 & 246 & 294 & 201 & 110 & 1012 \\
\hline Bulunma & $\%$ & 15,9 & 24,3 & 29,1 & 19,9 & 10,9 & 100 \\
\hline Gündemi & $\mathrm{F}$ & 129 & 119 & 213 & 282 & 269 & 1012 \\
\hline Takip & $\%$ & 12,7 & 11,8 & 21,0 & 27,9 & 26,6 & 100 \\
\hline Zaman & $\mathrm{F}$ & 160 & 163 & 234 & 242 & 213 & 1012 \\
\hline Geçirme & $\%$ & 12,7 & 11,8 & 21,0 & 27,9 & 26,6 & 100 \\
\hline
\end{tabular}

"Sosyal ağları en çok hangi amaçla kullanırsınız?" sorusu etrafında seçenekler sırası ile "yeni arkadaşlar bulmak, oyun oynamak, çevrimiçi sohbet etmek, arkadaşlarımı takip etmek, markaları takip etmek ve profilimi güncellemek, paylaşımda bulunmak, gündemi takip etmek, zaman geçirmek" şeklinde belirlenmiştir. Tabloya bakıldığında sosyal ağların en sık kullanılma amacı çevrimiçi sohbet etmek iken $(\% 45,1)$, en az kullanılma amacı ise markaları 
takip etmek $(\% 59,5)$ olarak karşımıza çıkmıştır. Bir önceki tabloyla ilişkilendirildiğinde gençler arasında WhatsApp'ın en fazla kullanılan sosyal ağ olması, sohbet etmek seçeneğinin yüksek olma oranını doğrulamaktadır. Buraya ayrıca dünya istatistiklerinde karşımıza çıkan Facebook Messenger'ın kullanıcı sayısını da eklemek gerekir (Çağala, 2017). Çevrimiçi sohbetlerin tablodaki yüksek oranı dikkate alındığında Messenger kullanımının da aynı olguyu desteklediği görülmektedir. Kuşkusuz bu durum bir sonraki adımda gençlerin sosyal çevreleriyle bağlarını koparttığının bir göstergesine dönüşmektedir. Gençlerin değer kaymasında sosyal ilişkilerden kopuş önemli bir bağlamdır. İnsani ilişkilerin zayıflaması bir sonraki süreçte sosyal etkileşimlerin kopmasına ve insanlar arasındaki iletişimin fiziksel karşılaşmalarda dahi gerçekleşmemesine neden olmaktadır. Sevgi, saygı, paylaşım vb. gibi birçok değerin de bu etkileşimlerde yaşanan kopmalarla anlamlarını kaybetmeye başladığı görülmektedir.

\subsection{Akıllı Telefonların Dönüştürdüğü Bir Gündelik Hayat}

İnsan, alet yapmaya ve yaptığı aletlerle doğayı kontrol gücü kurduğunda toplumsal bağlamı içerisinde taşıyan bir gündelik hayatın da ortaya çıkmaya başladığı görülmektedir. Kuşkusuz insanın zihinsel ve bedensel gücünün pratiğe dökülüşü olarak değerlendirilebilecek bu süreç, Sanayi Devrimi'nden yapayzekanın tartışılmaya başladığ günümüze kadar insan ontolojisinin inşa edici gücüdür. İnsan kontrol etme ve yönetme gücünü teknolojik araçlarla sürdürmek istemektedir. Akıllı telefonların yerleştirilebileceği en önemli bağlam da kendisini burada deşifre etmektedir. Fiziksel olarak içerisinde bulunduğu mekân ve zamanda yerel ve küreseli ifade eden çevresinde aynı anda bir yığın akışkanlığın parçası olmaktadır. Genç, kontrol etmekte, seyretmekte, yönetmekte ve kendisini dijital kodlara çevirmektedir. Akıllı telefonlar, bu bağlamda gençlerin gücünü artıran temel araçlardır. Kuşkusuz akıllı telefonlarla ilişkili birçok olumsuz durumun da tartışıldığı bir çağdan söz etmek mümkündür. Çalışmanın bu bölümünde telefonların dönüştürdüğü bir gündelik hayat teması işlenmiştir. 
Tablo 10. Kendisini Akıllı Telefonlara Bağımlı Hissetme Durumu

\begin{tabular}{lcc}
\hline Seçenekler & F & \% \\
\hline Hiç & 82 & 8,1 \\
Nadiren & 346 & 34,2 \\
Sık sık & 234 & 23,1 \\
Genellikle & 267 & 26,4 \\
Her zaman & 83 & 8,2 \\
Toplam & $\mathbf{1 0 1 2}$ & $\mathbf{1 0 0}$ \\
\hline
\end{tabular}

Katılımcılara sorulan "kendinizi akıllı telefonlara bağgmlı gibi hissettiğiniz oluyor mu?" sorusuna \%8,1'i hiç hissetmediğini ve \%34,2'si nadiren hisset-

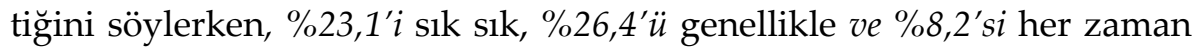
hissettiğini belirtmiştir. Bu oranlar katılımcıların büyük bir kısmının, nadiren seçeneği de dâhil edildiğinde kendilerini akıllı telefonlara bağımlı hissettiklerini söyledikleri saptanmıştır. Çalışmayla ilişkilendirilen bağımlılık kavramı negatif anlam içermektedir. Akıllı telefonlar, internete erişim noktası bağlamında kolay araçlar olduğundan bağımlılık yapma olasılıkları yüksek olmaktadır. Akıllı telefonların kullanımlarıyla ilgili bağımlılık, çalışma boyunca üç eksende değerlendirilmiştir. Bunlardan ilki akıllı telefondan kopamamaktır. Akıllı telefonla daha az vakit geçirmeye çalışıp da bunu başaramadıklarını ifade eden gençler bu bağlamda dikkate değerdir. Kendisini iyi hissetmek için akıllı telefonun kullanılması da bağımlılık bakımından dikkat çeken bir davranıştır. Gençlerin planladıkları zamandan daha uzun süre akıllı telefonla vakit geçirmeleri de önemli birer parametredir. Kuşkusuz burada akıllı telefon bağımlılığını gündeme getiren ikinci nokta "endişe etme" duygusudur. Telefon kapandığında yaşanan kaygı başta olmak üzere, şarj kablosuyla gezme, kafelerde prizlere yakın oturma, lavaboya giderken dahi telefonu yanından ayırmama gibi birçok tutum ve davranış bağımlılı̆̆ın endişe etme tarafına karşılık gelmektedir. Gençlerin birçoğunda araştırma sürecinde bu kaygıların görünür olduğu tespit edilmiştir. Bağımlılığı gündeme getiren üçüncü tavır ise gündelik hayatı tamamen akıllı telefona entegre yaşamaktır. Sabah kalkıldığında sosyal medyaya entegre bir şekilde başlayan gün, hikâye paylaşımları, fotoğraflar, profil incelemeleri, derslerde tahtaya yazılanların fotoğraflanması, ders WhatsApp grupları paylaşımlarıyla devam etmektedir. Akıllı telefon bağımlılığının çok daha ötesine taşınabilir duran dijital bağımlılık, doğrudan sanal mekanların bir 
parçası olmayı gündeme getirmektedir. Dijital bağımlılık; dinamik bir yaşamın içerisinde yer alınmasının yerine, sürekli bir ekrana bağımlı olmayı gerektirmesi açısından bilakis statik bir yaşam sürdürülmesine neden olmakta ve bu yönüyle de hareketsiz bir yaşam sürdürülmesi nedeniyle birçok fiziksel rahatsızlığa yol açabilmektedir (Kabakçı vd., 2008).

Çalışmada doğrudan akıllı telefonların bağımlılık yaptığını düşünmeyle ilişkili soru da yer almıştır. Katılımcılara "akıllı telefonların gençleri kendisine bağımlı yaptı̆̆ın düşünüyor musunuz?" biçiminde yöneltilen soruya katılımcıların \%87,4'ü evet yanttını verirken, \%9,4'ü ise bağımlı yapmadığı yanıtını vermiştir. Geri kalan \%3,3 ise kararsız kalmiştır.

Tablo 11. "Akıllı Telefonları özgürlü̈̆̈̈ kısıtlar" Sözüne Katılma Durumu

\begin{tabular}{lcc}
\hline Seçenekler & $\mathbf{F}$ & $\mathbf{\%}$ \\
\hline Hiç & 111 & 11,0 \\
Çok Az & 117 & 11,6 \\
Az & 102 & 10,1 \\
Orta & 158 & 15,6 \\
Fazla & 258 & 25,5 \\
Çok Fazla & 266 & 26,3 \\
Toplam & $\mathbf{1 0 1 2}$ & $\mathbf{1 0 0}$ \\
\hline
\end{tabular}

Katılımcilara "akıllı telefonlar özgürlüğ̈̈ kısıtlar" önermesine ne ölçüde katıldıkları sorulmuştur. Tabloya bakıldığında (\%26,3 çok fazla, \%25,5 fazla \%15,6 orta) araştırmada gençlerin akıllı telefonların özgürlüğü kısıtladığ1 önermesine katıldıkları tespit edilmiştir. Kuşkusuz akıllı telefonlarla özgürlügün kısıtlanması arasında kurulan ilişkide gençler için temel güdüleyici faktör, teknoloji bağımlılığına dönüşen bir telefon kullanımının söz konusu olmasıdır. Ayrıca gençler için bütün kişisel bilgilerin telefonda olması, telefonla kurulan özgürlük ilişkisinde bir diğer güdüleyici faktör olarak düşünülmüştür. Telefon kişiselleştirilmiş bir varlığa dönüşmüştür. Bu daha önce ifade edildiği bağlamda telefonun nesneden özneye dönüş sürecidir. Artık telefon, gençler için makineden çok öte bir anlam taşımaktadır. Aslında makinenin ötesine geçen bir teknolojinin varlığı, insanın anlam arayışında yeni bir dönemeci temsil etmesi bakımından önemlidir. 


\begin{tabular}{|c|c|c|c|c|c|}
\hline Seçenekler & & 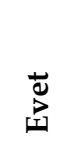 & $\stackrel{\grave{3}}{\stackrel{3}{I}}$ & 곯 & $\frac{\Xi}{\tilde{0}}$ \\
\hline \multirow[t]{2}{*}{ Akıllı telefonlar bireyi sosyalleştir mi? } & $\mathrm{F}$ & 392 & 435 & 185 & 1012 \\
\hline & $\%$ & 38,7 & 43,0 & 18,3 & 100 \\
\hline \multirow{2}{*}{$\begin{array}{l}\text { Akıllı telefon uygulamalarının sosyal dav- } \\
\text { ranışa bir etkisi var mıdır? }\end{array}$} & $\mathrm{F}$ & 717 & 217 & 78 & 1012 \\
\hline & $\%$ & 70,8 & 21,4 & 7,7 & 100 \\
\hline \multirow{2}{*}{$\begin{array}{l}\text { Akıllı telefonlar gençlerin yüz yüze ilişkile- } \\
\text { rini zayıflatır mı? }\end{array}$} & $\mathrm{F}$ & 818 & 134 & 60 & 1012 \\
\hline & $\%$ & 80,8 & 13,2 & 5,9 & 100 \\
\hline \multirow{2}{*}{$\begin{array}{l}\text { Akıllı telefonların sosyal ilişkileri zayıflat- } \\
\text { tığını düşünüyor musunuz? }\end{array}$} & $\mathrm{F}$ & 675 & 246 & 91 & 1012 \\
\hline & $\%$ & 66,7 & 24,3 & 9,0 & 100 \\
\hline
\end{tabular}

"Akıllı telefonlar bireyi sosyalleştirir mi?" başlıklı soruyla akıllı telefonların bireylerin dijital ortamda sosyal ağlar ile ne derecede sosyalleştiği tespit edilmek istenmiştir. Çıkan veriler sonucunda katılımcıların \%43'ünün akıllı telefonların bireyi sosyalleştirmediğini ifade ettikleri tespit edilmiştir. Katılımcıların $\% 38,7^{\prime} i$ ise akıllı telefonların bireyleri sosyalleştirdiğine inandıklarını ifade etmiştir.

"Akıllı telefon uygulamalarının sosyal davranışa bir etkisi var mıdır?" sorusuna verilen yanıtlara bakıldığında katılımcıların \%70,8'i uygulamaların sosyal davranışa etkisinin olduğunu belirttikleri görülmüştür. Bu uygulamalar üç alt başlıkta sorulmuştur. İlki kurumsal uygulamaların sosyal davranışlara etkisini belirlemeye dönük sorulmuştur. Burada katılımcların \%75'i kurumsal uygulamaların hayatlarını kolaylaştırdıklarını ifade ettikleri görülmüştür. Ancak oyun uygulamalarında ise tam tersi bir durum karşımıza çıkmıştır. Gençler arasında, oyun uygulamalarının kendilerini gündelik hayattan uzaklaştırdığını ifade edenlerin oranı \%47 iken; oyunlara ayrılan zamanla okula ayrilan zaman arasında oldukça fark gören katılımcıların oranı da \%53 olmuştur. Son olarak sosyal medya uygulamaların gündelik hayatta davranışı etkileyip etkilemediği sorulduğunda katılımcıların \%78'i etkilediğini ifade etmiştir. Özellikle sosyal medya uygulamaları söz konusu olduğunda "takip, beğeni, görüş" gibi olgular her ne kadar uygulama içindeki veriler de olsa bu olguların niceliksel sayıları gençlerdeki gündelik hayat motivasyonlarıyla doğrudan ilişkilidir. Böylece beğeni sayısı yüksek olan 
fotoğraflar, yorumlar, paylaşımlar vb. durumlar gündelik hayatta da bireyin davranışlarını etkilemektedir.

Sosyal medya hesaplarını akıllı telefonlar üstünden yöneten katılımclara "Akıllı telefonlar gençlerin yüz yüze ilişkilerini zayıflatır mı?" sorusu yöneltilmiştir. Tabloya bakıldığında katılımcıların \%80,8'i"evet zayıflatır" yanıtını vermiştir. Geri kalanların \%13,2'isi ise "hayır zayıflatmaz" cevabı vermiştir. "Akıllı telefonların sosyal ilişkileri zayıflattığını düşünüyor musunuz?" sorusunda gerçek hayat ve dijital hayat arasında ki paralellik sorgulanmıştır. Katılımcıların \%66,7'si akıllı telefonların sosyal ilişkileri zayıflattığını düşünürken, geri kalanların\%24,3'ü ise akıllı telefonların sosyal ilişkileri zayıflatmadığını düşündüklerini ifade etmiştir.

Tablo 13. Gençlerin Akıllı Telefonlan Kullanımlarıyla İlişkili Davranışlarının Dă̆ılımı

Seçenekler $\quad$ 离

\begin{tabular}{llccc}
\hline Akıllı telefonların hayatınızı ko- & F & 673 & 231 & 108 \\
laylaştırdığını düşünüyor musunuz? & $\%$ & 66,5 & 22,8 & 10,7 \\
\hline Akıllı telefonlar tembelliğe neden olur & $\mathrm{F}$ & 788 & 140 & 84 \\
mu? & $\%$ & 77,9 & 13,8 & 8,3 \\
\hline Sosyal medya hesaplarınızı çoğunlukla & $\mathrm{F}$ & 857 & 76 & 79 \\
akıllı telefonlardan mı yönetiyorsunuz? & $\%$ & 84,7 & 7,5 & 7,8 \\
\hline Akıllı bir telefonda ilk aranan şey inter- & $\mathrm{F}$ & 784 & 163 & 65 \\
net bağlantısı mıdır? & $\%$ & 77,5 & 16,1 & 6,4 \\
\hline Akıllı telefonların marka algısına yol & $\mathrm{F}$ & 740 & 223 & 49 \\
açtığını düşünüyor musunuz? & $\%$ & 73,1 & 22,0 & 4,8 \\
\hline Akıllı telefonların kullanımında serbest & $\mathrm{F}$ & 619 & 331 & 62 \\
zamanın çok olması etkili midir? & $\%$ & 61,2 & 32,7 & 6,1 \\
\hline Akıllı telefonların özellikleri gençleri & $\mathrm{F}$ & 767 & 182 & 63 \\
akıllı telefon kullanmaya teşvik eder mi? & $\%$ & 75,8 & 18,0 & 6,2 \\
\hline
\end{tabular}

"Akıllı telefonların hayatınızı kolaylaştırdığını düşünüyor musunuz?" sorusuna verilen yanıtlara bakıldığında katılımcıların \%66,5'i evet yanıtını verirken, $\% 22,8^{\prime} i$ ise hayır yanıtını vermiştir. Katılımcıların 
\%22,8'i ise akıllı telefonların gündelik hayatı kolaylaştırmadığını düşündüklerini ifade etmiştir. Buradan yola çıkarak akıllı telefonların gençlerin hayatını daha kolay hale getirdiğini söyleyenlerin oranı daha baskın çıkmıştır. Bu kolaylığın tembelliğe dönüşüp dönüşmediği ya da akıllı telefonların tembelliğe neden olup olmadığı bir sonraki soruda sorulmuştur. "Akıllı telefonlar tembelliğe neden olur mu?" sorusuna katılımcıların $\% 77,9^{\prime} u$ evet tembelliğe neden olur yanıtını vermiştir. "Sosyal medya hesaplarınız çoğunlukla cep telefonundan mı yönetiyorsunuz?" sorusuna katılımcıların \%84,7 gibi büyük bir oranı evet yanıtını vermiştir. Bağımlılık derecesi ölçülen bireylerin nelere bağımlı olduğu merak edilerek sorulan "Akıllı telefonda ilk aranan şey internet bağlantısı mıdır?" sorusuna katılımcıların $\% 77,5$ ' $i$ evet cevabını verirken, $\% 16,1$ oranı ise hayır yanıtını vermiştir. Bu orana bakıldığında internet bağlantısının kullanıcılar tarafından aranan temel özellik olduğu görülürken, internetin akıllı telefon kullanıcıları için ortak temel davranış güdüsü olduğu tespit edilmiştir.

"Akıllı telefonların markalaşmaya yol açtığını düşünüyor musunuz?" sorusunda akıllı telefon kullanıcılarının tüketim toplumuyla ilişkili markalarla ilgili tutumları tespit edilmek amaçlı sorulmuştur. Katılımcıların \%73,1'i evet akıllı telefonlar markalaşmaya yol açar, \%22'lik kısım ise hayır markalaşmaya neden olmaz yanıtını verdikleri görülmüştür. Gençler arasında yaygın olarak kullanılan serbest zaman kavramının herhangi bir işle doldurulabilecek vakit olarak algılanması sonucu bu zaman aralığını akıllı telefona ayırmaktadırlar. Akıllı telefon içindeki uygulamalar gençler arasında en fazla kullanılan uygulamalar olarak saptanmıştır. Bunlar sırasıyla çevrimiçi sohbet amaçlı kullanılan oyun uygulamaları, online alışveriş uygulamaları ve güncel haberleri takip ettiren uygulamalardır. Tabloya bakıldı̆̆ında katılımcıların \%61,2'si gençlerin akıllı telefon kullanımlarında belirleyici faktörün serbest zaman olduğunu ifade ettikleri görülmüştür. "Akıllı telefonların özellikleri insanları akıllı telefon kullanmaya teşvik eder" ölçütü ile uygulama hafızası ve özellikleri (kamera, kapasite, çözünürlük vb.) iyi olan akıllı telefonların gençler tarafından daha çok kullanılmakta olduğu gözlemlenmiştir. Katılımcıların $\% 75,8^{\prime} i$ akıllı telefonun özelliklerinin insanları akıllı telefon kullanmaya teşvik ettiğini düşündüğünü ifade etmiştir. 


\subsection{Kişisel Dönüşümlerden Toplumsal Dönüşümlere}

Akıllı telefonların etkilediği alan öncelikle bireyin kişisel dünyasıdır. Bireyin kendisinden başlayan bu değişim, sonrasında toplumsal alanının tamamına yayılma potansiyeli taşımaktadır. Böylece değişimlerin bireysel alandan kültürel alana doğru kayışının gündelik hayattaki hikayesi doğrudan akıllı telefonların gençlerin davranışları üzerine etkisi üzerinden okunabilmektedir. Araştırmanın bu kısmında akıllı telefonların toplumsal dönüşümlerle ilişkisi sorgulanmıştır.

\section{Tablo 14. Akıllı Telefonlarla İlgili Bazı Yargı ve Tutumlar}

\begin{tabular}{|c|c|c|c|c|c|}
\hline Seçenekler & & 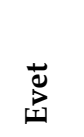 & $\stackrel{\vec{Z}}{\vec{Z}}$ & 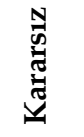 & $\frac{\Xi}{\overparen{a}}$ \\
\hline Akıllı telefonların gençleri & $\mathrm{F}$ & 772 & 161 & 79 & 1012 \\
\hline $\begin{array}{l}\text { bilinçsiz tüketim yapmaya } \\
\text { yönlendirmesi durumu }\end{array}$ & $\%$ & 76,3 & 15,9 & 7,8 & 100 \\
\hline Akıllı telefonların suç oranlarını & $\mathrm{F}$ & 771 & 132 & 109 & 1012 \\
\hline $\begin{array}{l}\text { yükselttiğine duyulan inanç du- } \\
\text { rumu }\end{array}$ & $\%$ & 76,2 & 13 & 10,8 & 100 \\
\hline
\end{tabular}

Teknoloji sürekli kendini yenilemektedir. Akıllı telefonlar da sürekli model yükseltmekte ve yeni özelliklerle tüketiciler karşısına çıkmaktadır. Her yeni model, kullanıcılar tarafından mutlaka ilgi çekmektedir ve piyasada yüksek satış rakamlarına ulaşabilmektedir. Bu bağlamdan hareketle katılımcılara yöneltilen "akıllı telefonların gençleri bilinçsiz tüketime yönelttiğini düşünüyor musunuz?" sorusuna katılımclların \%76,3'ünün evet, $\% 15,9^{\prime}$ unun ise hayır yanıtını verdikleri görülmüştür. Akıllı telefonlarda bulunan sınırsız sayıda uygulamayla kendi dünyalarını kuran bireyler, sanal dünyada başlarına gelecek tehlikeler hakkında çok az bilgiye sahiptir. İnternet dolandırıcılığı, siber zorbalık, istismar vb. suçların görüldüğü sanal ortamlara en hızlı ulaşan aygıt ise akıllı telefonlardır. "Akıllı telefonların toplumdaki suç oranların yükselttiğini düşünüyor musunuz?" sorusuna katılımcların\%76,2'si evet yanıtını verirken, \%13'ü ise hayır cevabını vermiştir. 


\begin{tabular}{|c|c|c|c|c|c|}
\hline Seçenekler & & 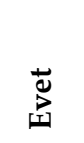 & 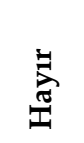 & 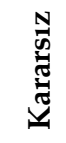 & 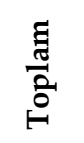 \\
\hline \multirow{2}{*}{$\begin{array}{l}\text { Akıllı telefonların bireyin kendi kendisiyle baş } \\
\text { başa kalmasında büyük bir engel olduğuna } \\
\text { inanıyor musunuz? }\end{array}$} & $\mathrm{F}$ & 780 & 173 & 59 & 1012 \\
\hline & $\%$ & 77,1 & 17,1 & 5,8 & 100 \\
\hline \multirow{2}{*}{$\begin{array}{l}\text { Akıllı telefonların bireyin vicdanıyla baş başa } \\
\text { kalmasının önünde engel olduğunu düşünüyor } \\
\text { musunuz? }\end{array}$} & $\mathrm{F}$ & 794 & 162 & 56 & 1012 \\
\hline & $\%$ & 78,5 & 16 & 5,5 & 100 \\
\hline
\end{tabular}

Akıllı telefonların gündelik hayatta neden olduğu temel değişimlerinden birisi insanlar arasındaki iletişimi hızlandırması olmuştur. Diğeri ise içerdiği uygulamalarla bireylerin üzerindeki gündelik hayat yükünü hafifletmek olmuştur. Bu yük, kişinin gündelik hayat içerisinde yapması gereken işlere ayırdığı zamanı ifade etmektedir. Bankacılık hizmetlerini uygulamalar üzerinden almak, öğrenci belgesi almak, adli sicil kaydı almak, uzaktan eğitim ders dinlemek gibi birçok eylem, akıllı telefon üzerinden çeşitli uygulamalarla gerçekleştirilmektedir. Akıllı telefon bağımlılığı, bireyin kendisiyle baş başa kalmasında önemli bir engeldir. Ayrıca telefondaki uygulamaların gönderdiği bildirimler, bireyin sürekli akıllı telefonla etkileşim halinde olmasına kaynaklık etmektedir. Bu bağlamda düşünüldügünde akıllı telefon kullanıcısı gençlerin aslında hiçbir zaman yalnız olmadıkları görülmektedir. Telefonuyla baş başa kalan birey, aslında belli bir akışkanlığın içerisinde sosyallik inşa etmektedir. Bu sosyallik sanal alemde olsa dahi bireyin sosyalliği açısından büyük önem taşımaktadır. Bu bağlamdan hareketle katılımcılara yöneltilen "akıll telefonlarm bireyin kendi kendisiyle baş başa kalmasında büyük bir engel olduğuna inanıyor musunuz?" sorusuna \%77,1'i evet yanıtını verirken, \%17,1 ise bu düşünceye katılmadığını belirtmiştir. "Akıllı telefonların bireyin vicdanıyla baş başa kalmasının önünde engel olduğunu düşünüyor musunuz?" sorusuna katılımcıların $\% 78,5^{\prime} i$ evet yanıtını vermiştir. 
Tablo 16. Akıllı Telefonların Dönüşümlerle İlişkisi Durumu

\begin{tabular}{|c|c|c|c|}
\hline Seçenekler & & $\mathbf{F}$ & $\%$ \\
\hline \multirow{3}{*}{$\begin{array}{l}\text { Akıllı Telefonların Bilginin Değerini Dö- } \\
\text { nüştürdügünü Düşünme }\end{array}$} & Evet & 728 & 72,0 \\
\hline & Hayır & 190 & 18,8 \\
\hline & Kararsiz & 93 & 9,2 \\
\hline \multirow{3}{*}{$\begin{array}{l}\text { Akıllı Telefonların Konuşma Dilinin Değerini } \\
\text { Azalttığını Düşünme }\end{array}$} & Evet & 723 & 71,4 \\
\hline & Hayır & 235 & 23,2 \\
\hline & Kararsız & 54 & 5,3 \\
\hline \multirow{3}{*}{$\begin{array}{l}\text { Akıllı Telefonların Gündelik Hayatta Sevgi ve } \\
\text { Saygı Kavramlarını Dönüştürdüğünü Düşünme }\end{array}$} & Evet & 691 & 68,3 \\
\hline & Hayır & 278 & 27,5 \\
\hline & Kararsız & 43 & 4,2 \\
\hline \multirow{3}{*}{$\begin{array}{l}\text { Akıllı Telefonların İnsanları Gerçek Hayattan } \\
\text { Koparttığını Düşünme }\end{array}$} & Evet & 757 & 74,8 \\
\hline & Hayır & 205 & 20,3 \\
\hline & Kararsiz & 50 & 4,9 \\
\hline
\end{tabular}

Akıllı telefonların icadı ile bilginin yayılma hızı da artmıştır. Bu hızla birlikte bilginin içeriğinin istenildiği gibi değiştirilmesi, kullanıcılar tarafından yeniden tanımlanması ve farklı şekillerde yorumlanması da söz konusu olmuştur. İnsanlar artık daha doğru bilginin hangisi olduğuna karar vermekte zorlanmaya başlamıştır. $\mathrm{Bu}$ insanları eskiyle kıyaslandığında daha kuşkucu ve endişeli yapmıştır. Bilginin neliği ile ilgili soruya verilen yanıtlara bakıldığında katılımcıların \%72'lik kısmı, akıllı telefonlarla birlikte gerçek bilginin ne olduğu konusunun tartışılır olmaya başladığına inandığını belirtirken, \%18,8'lik kısım ise böyle bir durumun oluşmadığı yanıtını verdikleri görülmüştür.

Akıllı telefonlar çevrimiçi sohbet uygulamaları ile daha fazla gündeme gelmiştir. Özellikle sosyal medya uygulamalarının birbirine entegre yapısı, WhatsApp' da yer alan gruplar ve kişilerle yazışmalar başta olmak üzere birçok pratik, bireylerde hız baskısı oluşturmaktadır. Aynı anda hikâye paylaşımları, hikayelere verilen yanıtlar, Facebook bildirimleri, WhatsApp sohbet bildirimleri gibi birçok uyarı bireyin aynı anda birçok parçaya bölünmesine neden olmaktadır. Burada Baudrillard'ın simülasyonun yeni bir evresiyle karşılaşılır. Böylece dijital evrende parçalara bölünmüş simülark özne, gerçek dünyayla değil gerçekliğin bir yanılsamasıyla muhatap olur (Baudrillard, 2011:13). Bu, akıllı telefonların bireyin gündelik hayatını fastfoodlaştırmasıyla doğrudan ilişkilidir. Bahsi geçen hız, konuşma dilini de flulaştırmıştır. Kelimeler kısaltılmaya, duygular 
emojilerle ifade edilmeye başlamıştır. Bu bağlamda katılımcılara yöneltilen "akıllı telefonların günlük hayatta kullanılan konuşma dilinin değerini azalttı̆̆ın düşünüyor musunuz?" sorusuna gençlerin \%71,4'i evet cevabını verirken \%23,2'si hayır yanıtını vermiştir. Bahsi geçen flulaşma sosyal ilişkilerin inşa edildiği güven kavramı üzerinde de yaşanmıştır. Bu bağlamda güven olgusunu sorgulayıcı sorulardan birisi olan "akıllı telefonların günlük hayattaki ilişkilerde sevgi ve saygının niteliğini değgistirdiğine inanyyor musunuz?"'a katılımcıların \%68,3'ü evet cevabını verirken \%27,5'i hayır cevabını vermiştir. Akıllı telefonlar insanları gerçek dünyadan uzaklaştırarak onlara kendi dünyalarını istedikleri gibi inşa etme fırsatı sunmuştur. Ancak uzun bir süre sonra sanal gerçeklik bireyi gerçek dünyadan koparmış ve onun gerçek ile sanal arasında ayrımı yapamaz hale getirmiştir. Bu durumla ilişkili olarak katılımclara yöneltilen soruda gençlerin \%74,8'i akıllı telefonların insanları gerçek hayattan koparttığını düşünürken, \%20,3'ü ise bu görüşe katılmadığını ifade ettiği görülmüştür.

\section{Sonuç}

İnsanlığın dijital devrim ile başlayan yeni hikayesinin sonunun nerede biteceği belirsiz görünmektedir. Bilgiye ulaşma kaygısının arama motorlarına entegre edildiği dijital varoluş alanında, en yoğun etkilenen kuşak da gençlerden oluşmaktadır. Akıllı telefon, dijital varoluş alanının temel kurucu aracıdır ve dönüşümlerin tam merkezinde bulunmaktadır. İnsanların yanlarından ayırmadığı, uygulamalarıyla gündelik hayatı hızlandıran, sosyalleşme ve serbest zaman değerlendirme aracı olan akıllı telefon, Ritzer'den ilhamla toplumun McSmartphonelaşmasına neden olmuştur. $\mathrm{O}$, yazılım ve kodlardan güç alarak bütün dünyayı "dijitalin demir kafesi" içine hapseden toplumsal, kültürel ve kimlik kurucu bir sistemin kendisine karşılık gelmektedir. Bu projenin yola çıkış noktası, bahsi geçen sistemin ve dönüşümün gençler üzerinden okunması kaygısı olmuştur. Çalışma Türkiye'nin farklı üniversitelerinde 1012 gençle yapılmış anket çalışmasının sonuçları kapsamıştır. Çalışmada ortaya çıkan bulgularda altı çizilesi noktaları şu şekilde sıralamak mümkündür.

- Akıllı telefonlar gençlerin bilgi konusunda tutumlarını ve tavırlarını olumsuz etkilemektedir. Bilginin değerinin düştüğüne inanan genç sayısı oldukça yüksektir. Günümüzde bilgiyi 
tanımlayan şey artık "basitlik", "tekdüzelik", "anlık işe yararlılık" ve "geçiciliktir".

- Akıllı telefonların gündelik hayatta güven ilişkisini kuran sevgi ve saygı kavramlarını dönüştürdüğüne inanan gençlerin sayısı yüksektir. Bu aynı zamanda telefonların gençleri gerçek hayattan koparttığına inanan bir kitlenin varlığını göstermektedir.dir de.

- Katılımclar sosyal medya hesaplarını, kolay taşınır ve anlık bağlantı özelliğiyle akıllı telefonlarla takip etmektedir. Akıllı telefon teknolojik araçtan ziyade özneleştirilmiş bir gündelik hayat fenomenine dönüşmüştür.

- Katılımcılar, kendilerini akıllı telefon bağımlısı olarak tanımlamakla birlikte akıllı telefonların özgürlüklerini kısıtladığını da ifade ettikleri tespit edilmiştir.

- Akıllı telefonlar gençlerin hayatlarını kolaylaştırmakta ve bu bakımdan gençlere cazip gelmektedir. Ancak gençlerin büyük bir çoğunluğunun akıllı telefonların tembelliğe sebep olduğu düşüncesine de katıldıkları görülmüştür.

- Kuşkusuz akıllı telefonlarla ilgili dikkat çekilesi noktalardan birisi de telefonların kişiyi kendisiyle ve vicdanıyla baş başa kalmasının önünde büyük bir engel olduğu önermesidir. McSmartphonelaşmanın en belirgin etkilerinden birisi bireyin kendi başına kalabileceği alanın artık yok edilmiş olmasıdır. Akıllı telefon gündelik hayatın her anında öznelliklerin önüne geçmektedir.

- Katılımcların gündelik hayatta konuşma dilinin eski değerinin kalmadığını ifade ettikleri görülmüştür. Akıllı telefon teknolojisine entegre edilmiş sosyal medya ve sohbet uygulamaları, bireyleri fiziksel olarak hızlanmaya zorladığı gibi düşünsel anlamda zorlamaktadır. Emojiler ve konuşma dilinin kısaltılması, akıllı telefonların dolaylı yoldan gündelik hayata etkisini göstermesi bakımından dikkat çekici bulunmuştur.

- Teknolojinin makineleştirdiği bir gündelik hayatta sosyal ilişkilerin nasıl bir yöne evrildiği önemli bir bağlamdır. Katılımcıların akıllı telefonların bireyleri sosyalleştirdiği düşüncesine katılmadığı görülmüştür. Telefonların sosyal davranışa etkisini olumsuz değerlendiren katılımcılar, gençlerin yüz yüze 
iletişimlerinin zayıflamasında da önemli bir etkisi olduğunu ifade etmişlerdir.

Akıllı telefonun uygulamaları, yazılımları ve kodlarıla birlikte insanın bütün duyu organlarının yerini alarak öznelleştiği bir dünyada yaşıyoruz. Kişinin gündelik hayatla bağını kopartan telefon, her şeyi tüketime dönüştürürken gerçeklikleri de görüntüye dönüştürmüştür. Artık McSmartphonelaşmanın tanımladığı anonim kimliksiz hayatlar söz konusudur. McSmartphonelaşmanın metaforik olarak "Prize bă̆lı hayatlar" olgusuyla özdeşleştirilmesi mümkündür. Priz, onları dijital dünyaya bağlayan yegâne kaynağa dönüştü.

Çalışmaya bir bütün olarak bakıldığında, gelecek projeksiyonuna akıllı telefonlarla ilgili birkaç noktayı eklemlemek mümkündür. İlk olarak kuşaklararasındaki makas, yeni kuşaklar lehine açılmaya devam edecektir. Çünkü bugün, dünyadaki değişimlere hızlı ayak uydurabilen, bilgiye rahat ulaşabilen, sanal kültürü gündelik hayata transfer eden ve mobil uygulamalarla gündelik hayatını kolaylaştıran yeni kuşak prototipi ortaya çıkmıştır. İkincisi gençlerin akıllı telefonlardan bağımsız bir kimlik inşaları mümkünsüz hale gelecektir. Gençlerin akıllı telefonlarla inşa ettiği mekân, aynı zamanda sanal alana ait bilgi ve kültürün gündelik hayatlarına transferini de ortaya çıkarmıştır. Son olarak akıllı telefon teknolojisinin gündelik hayatı baskı altında tutmaya devam ettiği süreçte gençlerin toplumla entegre bir hayat yaşamaları zorlaşacaktır. Bu durum kuşkusuz eski kuşaklarda şok dalgaları yaratacaktır. İlk şok dalgası geleneksel tutumların çözülüşünden doğan boşluğun doldurulduğu modüler değerler ve tutumların yaratacağı etkidir. İkinci şok dalgası sınırları belirli ancak içeriği her an değişebilen sosyalliklerin yaratacağ1 etkidir. Üçüncü şok dalgası ise bireyin ihtiyaç duymadığı bir sosyal realitenin toplumsalın sonunu haber vereceği zamana yaklaşmış olmanın etkisidir. Bu bağlam, aynı zamanda "Belirsizlikler Çă̆ı"ndan "Belirlilikler Çă̆ı" na geçişin habercisi olduğu gibi "insan"ın bir özne olarak yeniden tartışılmasının da başlangıç noktası olacaktır. 


\title{
EXTENDED ABSTRACT
}

\section{The Impact of Smart Phones on Young People's Daily Life: Example of University Youth in Turkey}

\author{
Adem Sağır - Hasan Eraslan
}

\section{Karabük University}

It is seen uncertain about where the humanity's new story beginning with the digital revolution will end. The most-affected generation consists of the young people in the field of digital existence that the anxiety of reaching the information is integrated to the search engine. The smart phone is the main founder instrument of the digital existence area and it is exactly in the centre of transitions. The smart phone that the people always keep with them, which accelerates the daily life with its applications and is the socialization and free-time valuation intrument has caused that the society become smartphone with the inspiration from Ritzer. It corresponds to the the system which incloses the whole world into " the iron cage of digital" with getting power from the software and codes, and which is the founder of society, culture and identity. The starting point of this project is the anxiety that the aforementioned system and transition are seen on the young people. The social structures which are covered with the globalization regenerate themselves with the points attracting notice in many fields from the people's attitudes to the cultural practicals. Especially, the technological innovations which are constantly renewed change and transform the aspect of globalization. The reality which is focused in this study is " the smart phones" which have become the main part of the information technologies. It is possible to describe the negative aspects of smart phones besides their life-facilitating aspects. While the smart phones lead to a result which directly separates the social relations and causes the disassociation between the communication networks, they have been a popular consumption tool as being an obstacle to the active usage of mind and thinking. It is seen that the social control and pressure mechanisms have been regenerated around these devices among the young people. 
This study was prepared from the point of a study's data which was supported by TÜBİTAK and in the sample of Turkey's youth. The young people's direct interaction with the technology has been effective that the university youth was prefered as the sampling. The university students were chosen in the sample of Istanbul, Bursa, Ankara, Konya, Izmir, Trabzon, Çankırı, Karabük, Isparta, Aksaray, Elâzı̆̆, Mersin in accordance with their provinces in the research. The study is an important study which was made in its field in terms that the smart phones had impression on the young people's social attitudes and values in the sample of Turkey. The study included the result of a survey which was made with 1012 young people in the different countries in Turkey. It is possible to say the highlighted points in the findings which appeared in the study.

- The smart phones affect negatively on the young people's attitudes and behaviors related to the information. The number of young people who think that the value of information has decreased is very high. The point to describe the information is "simple", " uniform" and "temporariness" today.

- The number of young people who believe that the smart phones transform the concepts of love and respect which create the reliance relationship in the daily life is high. At the same time, they are the population which believe that the phones take the young people apart from the real life.

- The participants have their social media accounts with the smart phones which can be easily carried and have the instant connection. The smart phone has turned in a daily life phenomenon, which has been made subjective, rather than the technological device.

- The participants described themselves as the addict to the smart phone. Moreover, it was determined that they stated that the smart phones restrict their freedom.

- The smart phones make the young people's life easy so they become attractive for the young people. However, it was seen that most of young people agreed in the view that the smart phones caused the laziness.

- There is no doubt that one of the interesting points related to the smart phones is that the phones offer that there is a great obstacle 
for a person to be hisseli/herself and his/her conscience in private. One of the most explicit effects of being McSmartphone is that the area where an individual can be with himself/herself has been destoryed no longer. The smart phone precludes the individual's subjectivity in each time of daily life.

- It was seen that the participants stated that spoken language has not had its last value in the daily life. The social media and chatting applications which are integrated to the smart phone technology forces the individuals physically and the in the intellectual sense. The emotions and abbreviations of the spoken language were found very interesting in terms that the smart phone has indirectly an effect on the daily life.

- It is an important sense what a direction the social relationships have evolved in the daily life that the technology has mechanised it. It was seen that the participants disagreed in the view that the smart phones socialize the people. The participants who considered the phones' negative effect on the social behavior stated that they have an important effect on the manner that the young people's face-to-face communication reduces.

We live in the world where all of the people's sense organs become subjective with the smart phone applications, software and codes. The phone separating the person from the daily life transformed everything to the consumption and reality to the image. Now, the anonymous lives without an identity being McSmartphone describes them are available. It is possible that being McSmartphone is assimilated with the fact of "the lives connected to the socket" metaphorically. The socket has turned into a single source connecting them to the digital world.

When the study is considered as a whole, it is possible to add some points related to the smart phones to their future projection. Firstly, the intergenerational points will be greater for the new generations. Because a new generation prototype which can adapt the world's changings quickly, can reach the information easily, transfer the imaginary culture to the daily life and makes the daily life easy with the mobile applications has arisen today. Secondly, it will be impossible that the young people make an independent identity from the smart phones. The place that the young people have made with the smart phones has also revealed the 
transfer of information and culture belonging to the imaginary field to their daily life. Finally, it will be very difficult that the young people have a life integrated in the society in a process that the smart phone technology goes on keeping the daily life under the pressure. This situation will definitely create a shocking waves among the old generations. The first shocking wave is the effect that the modular values and attitudes that the gap arising from the dissociation of traditional attitudes are filled with them will create it. The second shocking wave is the effect that the sociability that its limits are certain but its content can change at any time will create it. The third shocking wave is the effect of being close to the time when a social reality that an individual doesn't need it will inform the social end. This context will be also the starting point for the manner that "the man" is discussed again as a subject besides being a harbinger of passing from " The Age of Uncertainty" to "The Age of Certainty".

\section{Kaynakça / References}

2018 İsraf Raporu, https://www.ticaret.gov.tr/haberler/2018-israf-raporuaciklandi, Erişim Tarihi:25.02.2019.

Baudrillard, J. (2011). Simülakrlar ve Simülasyon. (Çev: Oğuz Adanır), Ankara: Doğu Batı Yayınları.

Bauman, Z. (2017). Kimlik. (Çev: Mesut Hazır), Ankara: Heretik Yayıncılık Bayrak, H.(2018). "2018 internet kullanım ve sosyal medya istatistikleri", https://dijilopedi.com/2018-internet-kullanimi-ve-sosyal-medyaistatistikleri/, Erişim Tarihi: 21.01.2019

Bookchin, M. (1996). Ekolojik bir topluma doğru. (Çev: Abdullah Yılmaz), İstanbul: Ayrintı Yayınları.

Castells, M. (2001) The internet galaxy. Reflections on the internet, business and society. New York: Oxford UniversityPress

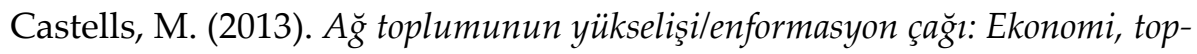
lum ve kültür. Cilt 1, (Çev:Ebru Kılıç), İstanbul: Bilgi Üniversitesi Yayınları.

Choudhary, A. (2014). Smartphones and their impact on net income per employee for selected U.S. firms. Review of Business and Finance Studies, 5(2), 9-17. 
Çağala, C. (2017). Dünyada en çok kullanılan sosyal medya platformları (Analiz), https://www.tech-worm.com/dunyada-en-cok-kullanilansosyal-medya-platformlari-analiz/, Erişim Tarihi: 02.02.2019

De Prato, G. Feijoo, C., Simon, J. P. (2014). Innovations in the video game industry: Changing global markets. Digiworld Economic Journal, 94(2), $17-38$.

Digital in 2018, https://wearesocial.com/blog/2018/01/global-digital-report-2018, Erişim Tarihi: 20.01.2019.

Giddens, A. (2014). Modernite ve bireysel kimlik geç modern çă̆da benlik ve toplum. (Çev: Ümit Tatlıcan), İstanbul: Say Yayınları.

İslamoğlu, H. ve Alnıaçı, Ü. (2016). Sosyal bilimlerde araştırma yöntemleri. İstanbul: Beta Yayınları.

Ling, R. (2004). The mobile connection. The cell phone's impact on society. San Francisco: Morgan Kaufmann.

Mac Sithigh, D. (2012). App law within: Rights and regulation in the smartphone age. Edinburgh University School of Law Research Paper, 22, 154-186.

Mora, N. (2008). Medya ve kültürel kimlik. Uluslararası İnsan Bilimleri Dergisi, 5 (1), 1-14.

Ritzer, G.(2016). Toplumun McDonaldlaştırılması. (Çev:Şen Süer Kaya), İstanbul: Ayrıntı Yayınları.

Timisi, N.(2005). “Sanallığın gerçekliği: İnternetin toplum ve kimlik alanlarına girişi", İnternet, Toplum, Kültür, (Derleyenler), Mutlu Binark ve Barış Kılıçbay. İstanbul: EposYayınları. s.89-105.

Yılmaz, E. (2017). "Akıllı telefon kullanım yaşı 9'a indi", https://www.aa.com.tr/tr/bilim-teknoloji/akilli-telefon-kullanimyasi-9a-indi/808787, Erişim Tarihi: 20.01.2019

\section{Kaynakça Bilgisi / Citation Information}

Sağır, A. ve Eraslan, H. (2019). Akıllı telefonların gençlerin gündelik hayatlarına etkisi: Türkiye'de üniversite gençliği örneği. OPUSUluslararası Toplum Araştırmaları Dergisi , 10(17), 48-78. DOI: 10.26466/opus.515339 